\title{
Efficacy of topical hyaluronic acid for symptomatic oral lichen planus: A systematic Review.
}

\section{Eficacia del ácido hialurónico tópico para el liquen plano oral sintomático: Revisión Sistemática.}

Sadeq A. Al-Maweri. ${ }^{1}$

Rawan Alanazi. ${ }^{2}$

Mohammed Nasser Alhajj. ${ }^{3}$

Ammar Daer. ${ }^{4}$

Abdulrahman Ahmed Hunaish. ${ }^{5}$

Abdullah Bin Nabhan. ${ }^{6}$

Abeer A. Al-Sosowa. ${ }^{7,8}$

Affiliations:

${ }^{1}$ College of Dental Medicine, QU Health, Qatar University, Qatar.

Vision College of Dentistry and Nursing, Riyadh, Saudi Arabia.

${ }^{3}$ Department of Prosthodontics, Faculty of Dentistry, Thamar University, Dhamar, Yemen.

4Faculty of Dentistry, McGill University, Montreal, Canada; Department of Orthodontics, Faculty of Dentistry, Sana'a University, Yemen.

${ }^{5}$ Department of Oral \& Maxillofacial Surgery, AlFarabi colleges, Riyadh, Saudi Arabia.

${ }^{6}$ Department of Oral \& Maxillofacial Surgery and Diagnostic Sciences, College of Dentistry, Prince Sattam Bin Abdulaziz University, AlKharj, Saudi Arabia.

'Department of Periodontics, School of Stomatology, Lanzhou University, Lanzhou, China.

${ }^{8}$ Department of Periodontics, Faculty of Dentistry, Thamar University, Dhamar, Yemen.

Corresponding author: Mohammed Nasser Alhajj. Department of Prosthodontics, Faculty of Dentistry, Thamar University, Dhamar, Yemen. Email: m.n.alhajj@hotmail.com

Receipt : 10/02/2020 Revised: 04/20/2021 Acceptance: 08/29/2021

Al-Maweri SA, Alanazi R, Alhajj MN, Daer A, Hunaish AA, Nabhan AB \& Al-Sosowa AA. Efficacy of topical hyaluronic acid for symptomatic oral lichen planus: A Systematic Review.

J Oral Res 2021; 10(4):1-7.

Doi:10.17126/joralres.2021.056

1

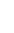

Abstract: Background: Oral lichen planus (OLP) is a chronic inflammatory disorder with a potential of malignant transformation. Despite the extensive research on the topic, the management of OLP is still quite challenging, with no definitive cure. Objective: The present systematic review assessed the efficacy of topical hyaluronic acid in the management of OLP. Material and Methods: A comprehensive search of PubMed, Scopus, Web of Science and Google Scholar was carried out by two independent investigators. All randomized clinical trials that compared the efficacy of hyaluronic acid with other interventions and/or placebo in the management of OLP and fulfilled the following criteria were included: 1) OLP diagnosis was confirmed clinically and histopathologically, 2) the study included systemically healthy patients aged 15 years and older, 3) a minimum sample size of 10 , and 4) reporting the main outcomes including pain, erythema, and ulcer size. Case reports, case series, reviews, animal studies, uncontrolled trials were excluded. Results: Four clinical trials involving 234 patients were included. Two studies compared hyaluronic acid with a topical corticosteroid, and two studies compared it with placebo. Only one of the four included studies was at low risk of bias. Overall, topical hyaluronic acid showed good efficacy in alleviating the signs and symptoms of OLP. Two studies found hyaluronic acid significantly more effective in reducing pain and improving clinical signs of OLP compared to placebo. Compared to topical corticosteroids, one study reported comparable results; and one study found hyaluronic acid to be superior to triamcinolone in reducing pain but inferior to triamcinolone in improving the healing time. Conclusion: The limited available evidence suggests that hyaluronic acid may have some benefits in the management of OLP. Further well-designed studies with adequate follow-up periods are highly recommended.

Keywords: hyaluronic acid; lichen planus, oral; efficacy; systematic review; pain; erythema. 
Resumen: Antecedentes: el Liquen Plano Oral (LPO) es un trastorno inflamatorio crónico con potencial de transformación maligna. A pesar de la extensa investigación sobre el tema, el manejo de LPO sigue siendo bastante desafiante, sin cura definitiva. Objetivo: La presente revisión sistemática evaluó la eficacia del ácido hialurónico tópico en el tratamiento del LPO. Material y Métodos: dos investigadores independientes llevaron a cabo una búsqueda exhaustiva en PubMed, Scopus, Web of Science y Google Scholar. Se incluyeron todos los ensayos clínicos aleatorizadosquecompararonlaeficaciadelácidohialurónico con otras intervenciones y / o placebo en el manejo del LPO y cumplieron con los siguientes criterios: 1) el diagnóstico de LPO se confirmó clínica e histopatológicamente, 2) el estudio incluyó pacientes sistémicamente sanos de edad avanzada 15 años o más, 3) un tamaño de muestra mínimo de 10, y 4) informar los resultados principales, incluido el dolor, el eritema y el tamaño de la úlcera. Se excluyeron informes de casos, series de casos, revisiones, estudios en animales y ensayos no controlados. Resultados: Se incluyeron

\section{INTRODUCTION.}

Oral lichen planus (OLP) is a chronic inflammatory disorder with a potential of malignant transformation. ${ }^{1}$ It is a relatively common condition affecting 0.5-2\% of the general population. ${ }^{2,3}$ Middle-aged adults are typically affected, with a slight female predilection. ${ }^{2,3}$ Despite the extensive research and advances in knowledge, the etiopathogenesis of OLP is still poorly understood. ${ }^{1,4}$ However, recent evidence suggests an autoimmune response to various local and systemic trigger factors. ${ }^{1-7}$

Clinically, OLP can present in different forms: reticular, atrophic, erosive, pigmented, and plaqueform. ${ }^{1}$ While the reticular form (the most common form) is usually painless, erosive and atrophic forms are very painful that can interfere with daily functions such as eating and speaking. Thus, OLP can gravely impact the patients' quality of life that necessitates immediate medical attention. ${ }^{1,8}$ In addition to pain and discomfort, OLP, especially erosive and atrophic forms, is considered a potentially malignant disorder with an estimated transformation rate of 1.14\%. ${ }^{9}$

Given the obscure etiopathogenesis of OLP, there cuatro ensayos clínicos con 234 pacientes. Dos estudios compararon el ácido hialurónico con un corticosteroide tópico y dos estudios lo compararon con un placebo. Sólo uno de los cuatro estudios incluidos tuvo bajo riesgo de sesgo. En general, el ácido hialurónico tópico mostró una buena eficacia para aliviar los signos y síntomas del LPO. Dos estudios encontraron que el ácido hialurónico es significativamente más eficaz para reducir el dolor y mejorar los signos clínicos del LPO en comparación con el placebo. En comparación con los corticosteroides tópicos, un estudio informó resultados comparables; y un estudio encontró que el ácido hialurónico es superior a la triamcinolona para reducir el dolor pero inferior a la triamcinolona para mejorar el tiempo de curación. Conclusion: La evidencia disponible limitada sugiere que el ácido hialurónico puede tener algunos beneficios en el manejo del LPO. Se recomienda realizar más estudios bien diseñados con períodos de seguimiento adecuados.

Palabra Clave: ácido hialurónico; liquen plano oral; eficacia; systematic review; dolor; eritema.

is no specific therapy as yet, and the management is primarily directed at controlling pain and reducing the healing time. ${ }^{1,5,10} \mathrm{~A}$ number of pharmacological and non-pharmacological modalities have been used for the management of OLP.1,11,12 These include corticosteroids, calcineurin inhibitors, immunosuppressant agents, laser therapy, and photodynamic therapy, among others. ${ }^{11-13}$ Among these, corticosteroids (topical and systemic) are the most widely accepted treatment option for OLP. ${ }^{12}$

However, long-term use of corticosteroids is occasionally associated with several systemic and local complications that limit their use. ${ }^{11,12}$ Additionally, the use of corticosteroids is contraindicated in patients with certain conditions such as diabetes mellitus, hypertensive, gastric ulcer, and during pregnancy. Hence, there is an urgent need to search for another alternative therapy for OLP. ${ }^{11,12}$

Recently, hyaluronic acid (HA) has been proposed as a new therapeutic modality for several inflammatory conditions, including OLP.8,10 HA is a linear polymer of glucuronic acid (acetylglucosamine disaccharide), which can be found in many tissues and body fluids. ${ }^{14}$ 
The primary function of HA appears to be in tissue healing through different mechanisms, including moderation of the inflammatory responses, promoting cell proliferation, and promoting re-epithelization via the proliferation of basal keratinocytes. ${ }^{14,15}$ Additionally, HA has been shown to have analgesic and potent anti-inflammatory effects; ${ }^{16-18}$ it inhibits the expression of mediators of nociceptive pain, such as prostaglandin E2, cyclooxygenase- 2, and adenosine 5'-triphosphate. ${ }^{16,18,19}$

HA has been used for the ma-nagement of several systemic and oral conditions such as osteoarthritis, temporomandibular joint disorders, dry socket, and recurrent oral ulcers. ${ }^{16,19,20}$ In this context, a number of clinical trials have tried HA in the management of OLP, and reported conflicting results. ${ }^{8,10,21,22}$

Nevertheless, no systematic review has evaluated the efficacy of HA in the management of OLP thus far. Therefore, the present systematic review sought to summarize the available evidence regarding the efficacy of HA in reducing signs and symptoms in OLP patients.

\section{MATERIALS AND METHODS.}

\section{Focused question}

The present systematic review was conducted in full accordance with the Reporting Items for Systematic Review and Meta-Analysis (PRISMA) guidelines. ${ }^{23}$ The formulated PICO (Participants, Intervention, Control, and Outcome) question was: "Is topical HA effective in the management of symptomatic OLP?"

\section{Eligibility criteria}

All randomized clinical trials that compared the efficacy of hyaluronic acid with other interventions and/or placebo in the management of OLP and fulfilled the following criteria were included:

1) OLP diagnosis was confirmed clinically and histopathologically;

2) The study included systemically healthy patients aged 15 years and older;

3) A minimum sample size of 10 , and

4) Reporting the main outcomes including pain, erythema, and ulcer size. Case reports, case series, reviews, animal studies, uncontrolled trials were excluded.

\section{Search strategy}

A comprehensive literature search of online databases (PubMed, Scopus, Web of Science, and Google scholar) was carried out by two independent authors (RA and SA) for all relevant articles, using a combination of the following keywords: "hyaluronic acid" OR "hyaluronan" AND "oral lichen planus" AND "OLP"). No language or time restrictions were imposed. Additionally, a manual search of the retrieved references was conducted for any additional studies. The title and abstract of the retrieved studies were screened by two reviewers independently, and irrelevant studies were excluded. A full-text of all potentially eligible studies were then obtained and read by the two reviewers for inclusion.

\section{Quality assessment}

The quality of all included studies was assessed by two authors independently (RA and MA) following the revised recommendations of the Consolidated Standards of Reporting Trials Statement (CONSORT). ${ }^{24}$ Seven domains were assessed: sample size calculation; randomization and allocation concealment methods; a clear definition of inclusion and/or exclusion criteria; withdrawals/dropouts report; baseline comparability between the groups; the presence of blinding; and appropriate statistical analysis.

Accordingly, the overall risk of bias for each study was judged as either: low if all standards met; moderate, if at least one standard halfway met; or high if one or more standards were not met.

\section{Data Extraction}

The following data were extracted and tabulated using special forms: author and country of the study, age and gender of the participants, dose and frequency of the medication, follow-up period, type of OLP, evaluation methods, and the main outcomes.

\section{RESULTS.}

\section{Study selection}

Figure 1 illustrates the search strategy. Out of the 46 identified articles, 24 were duplicates and thus were removed. Screening titles and abstracts of the potentially eligible 22 articles revealed that 14 articles were irrelevant and thus were excluded. The fulltext articles of the remaining 8 studies were sought and read by two authors for inclusion; of these, four articles did not meet the inclusion criteria (two review articles, one study without control group, and one 
editorial article), and so were excluded. Eventually, 4 articles met the inclusion criteria and were processed for data extraction.

\section{Study general characteristics}

General characteristics of the included studies are presented in Table 1. Four randomized clinical trials involving 234 patients were included.8,10,21,22 Two studies were conducted in Egypt, ${ }^{10,21}$ one in the UK, ${ }^{8}$ and one in India. ${ }^{22}$ The number of the subjects ranged between 20 and 124, with age ranging between 17 and 75 years. Female subjects comprised the majority of the subjects in most of the included studies. With regards to the comparison group, HA was compared with topical triamcinolone in two studies, ${ }^{10,21}$ and with placebo in the other two studies. ${ }^{8,22}$ The diagnosis of OLP was confirmed by histopathology in all included studies. The follow-up period ranged from 28 days to three months. Three studies used 0.2\% HA gel, 8,10, 21 while one study used 0.2\% HA orabase. ${ }^{22}$ (Table 1).

\section{Outcomes measures}

All included studies evaluated the efficacy of HA on reducing pain and clinical signs of OLP (e.g., reduction in erythema and size of the lesions). The severity of pain was recorded using the Visual Analogue Scale (VAS) in all of the included studies. With regards to the clinical improvement, one or more of the following parameters were assessed: level of erythema, the size of the ulcer/erosion, and functional ability (Table 1).

\section{Main outcomes}

All included studies showed a good efficacy of HA in reducing clinical signs and symptoms of OLP. Two studies found superior results in favour of $\mathrm{HA}$ compared to placebo. ${ }^{8,22}$ One study reported the equivalent efficacy of $\mathrm{HA}$ and topical corticosteroids in reducing pain and resolution of clinical signs; ${ }^{10}$ one study ${ }^{21}$ found HA to be more effective than topical corticosteroids in reducing pain but less effective in reducing clinical signs (Table 1 ).

\section{Quality of the included studies}

Error! Reference source not found. 2 illustrates the results of the CONSORT-based quality of the included studies. Only one study ${ }^{8}$ was at a low risk of bias, while the remaining 3 studies were at high risk of bias. ${ }^{10,21,22}$ The most common unmet standards were the lack of sample size calculation (criteria A), and the lack of or improper blinding (criteria F). (Table 2)

Figure 1. Flow chart of methodology

IDENTIFICATION

SCREENING

ELIGIBILITY
Records identified through database $(n=46)$

(Duplicates $=24$ )

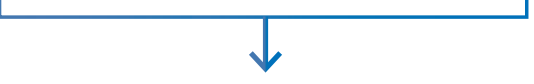

Records after duplicates removed $(n=22)$

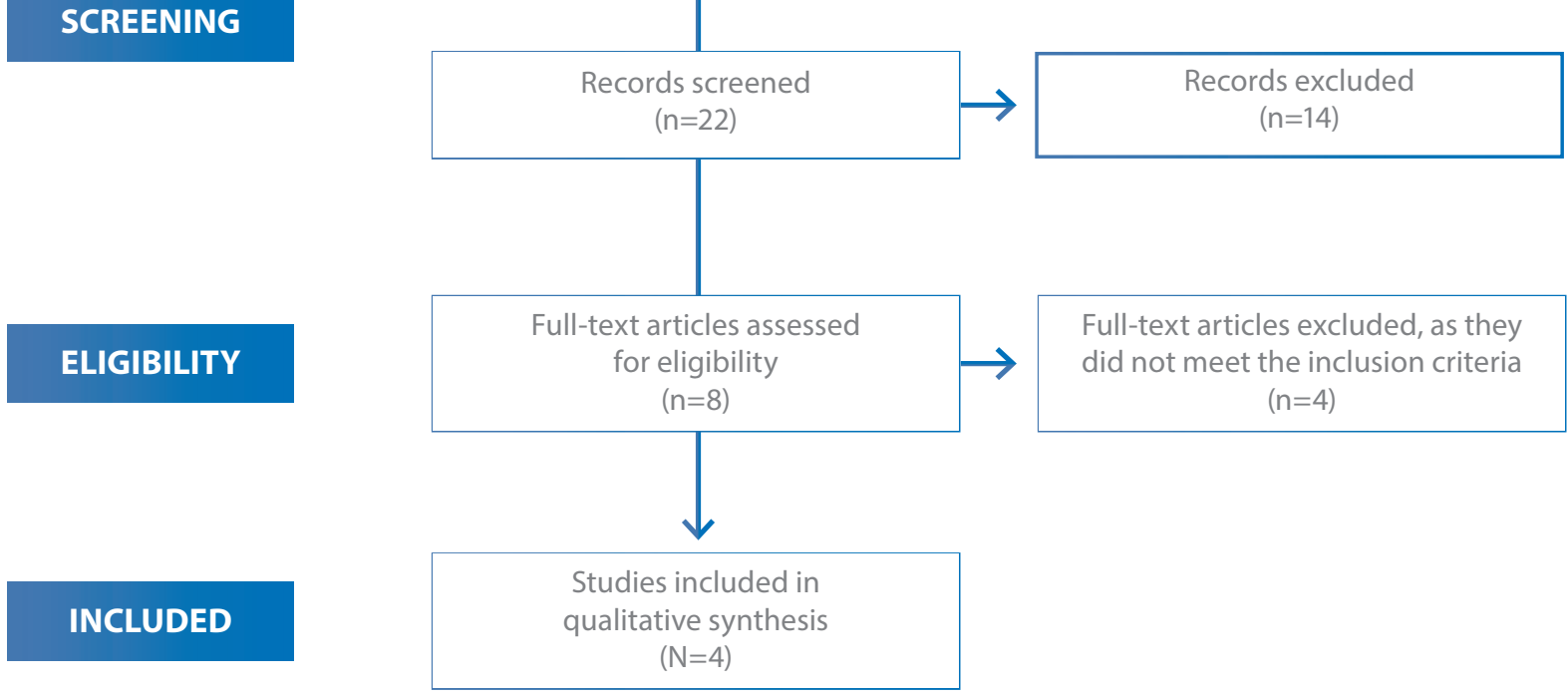


Table 1. General characteristics of the included studies.

\begin{tabular}{|c|c|c|c|c|c|}
\hline $\begin{array}{l}\text { Authors, Year } \\
\text { and country }\end{array}$ & $\begin{array}{l}\text { Study groups } \\
\text { (sample size and age) } \\
\text { Gender: Male, Female }\end{array}$ & $\begin{array}{l}\text { Dose } \\
\text { (Follow-up } \\
\text { period) }\end{array}$ & $\begin{array}{l}\text { Type } \\
\text { of OLP }\end{array}$ & $\begin{array}{l}\text { Evaluation } \\
\text { methods }\end{array}$ & Outcome \\
\hline $\begin{array}{l}\text { Hashem } \\
\text { et al., }{ }^{10} \\
2019 \\
\text { (Egypt) }\end{array}$ & $\begin{array}{l}\text { Intervention: HA }(n=20) \\
\text { Age: } 54.34 \\
\text { Gender: } 9 / 11 \\
\text { Control: } \\
\text { Triamcinolone }(n=20) \\
\text { Age: } 55.87 \\
\text { Gender : } 8 / 12\end{array}$ & $\begin{array}{l}\text { Topical HA } \\
0.2 \% \text { gel } 3 / \text { day } \\
\text { for } 30 \text { min } \\
\text { for } 28 \text { days } \\
\text { ( } 28 \text { days) }\end{array}$ & $\begin{array}{l}\text { Erosive } \\
\text { Atrophic } \\
\text { combined }\end{array}$ & $\begin{array}{l}\text {-Pain VAS } \\
\text {-Lesion size } \\
\text { - Healing signs } \\
\text { (erythema) }\end{array}$ & $\begin{array}{l}\text { HA was as effective as } \\
\text { triamcinolone in reducing } \\
\text { pain and clinical signs, with } \\
\text { no significant difference } \\
\text { between the groups }(p>0.05)\end{array}$ \\
\hline $\begin{array}{l}\text { Youssef } \\
\text { et al., }{ }^{21} \\
2019 \\
\text { (Egypt) }\end{array}$ & $\begin{array}{l}\text { Intervention: HA }(\mathrm{n}=10) \\
\text { Age: > } 35 \\
\text { Gender: NA } \\
\text { Control: } \\
\text { Triamcinolone }(\mathrm{n}=10) \\
\text { Age: > } 35 \\
\text { Gender: NA }\end{array}$ & $\begin{array}{l}\text { Topical HA } \\
0.2 \% \text { gel and, } \\
4-5 / \text { day } \\
\text { for } 28 \text { days } \\
\text { ( } 3 \text { months) }\end{array}$ & Erosive & $\begin{array}{l}\text { Pain VAS } \\
\text {-Lesion size, } \\
\text { healing signs } \\
\text {-Histological }\end{array}$ & $\begin{array}{l}\text { HA was more effective than } \\
\text { triamcinolone in reducing } \\
\text { pain, but triamcinolone } \\
\text { showed superior results in } \\
\text { reducing healing time. }\end{array}$ \\
\hline $\begin{array}{l}\text { Sheety } \\
\text { et al..,2 } \\
2016 \\
\text { (India) }\end{array}$ & $\begin{array}{l}\text { Intervention: HA ( } n=25) \\
\text { Age: 17-75 } \\
\text { Gender: 13/12 } \\
\text { Age: } 26-70 \\
\text { Gender: } 11 / 14\end{array}$ & $\begin{array}{l}\text { Topical HA } \\
0.2 \% \text { orabase } \\
3 / \text { day } \\
\text { for } 30 \text { min } \\
\text { For } 28 \text { days } \\
\text { (28 days) }\end{array}$ & $\begin{array}{l}\text { Erosive } \\
\text { Reticular } \\
\text { Atrophic } \\
\text { pigmented }\end{array}$ & $\begin{array}{l}\text { Pain VAS } \\
\text {-lesion size, } \\
\text { healing signs }\end{array}$ & $\begin{array}{l}\text { HA was significantly more } \\
\text { effective than placebo in } \\
\text { reducing pain and clinical } \\
\text { signs, with no adverse effects. }\end{array}$ \\
\hline $\begin{array}{l}\text { Nolan } \\
\text { et al., } \\
2009 \\
\text { (UK) }\end{array}$ & $\begin{array}{l}\text { Intervention: } \mathrm{HA}(\mathrm{n}=62) \\
\text { Age: } 55.3 \\
\text { Gender: } 9 / 53 \\
\text { Control: placebo }(\mathrm{n}=62) \\
\text { Age: } 56.46 \\
\text { Gender:15/47 }\end{array}$ & $\begin{array}{l}\text { Topic HA } 0.2 \% \\
\text { gel } 4-5 / \text { day } \\
\text { for } 28 \text { days } \\
\text { ( } 28 \text { days) }\end{array}$ & Erosive & $\begin{array}{l}\text { Pain VAS } \\
\text {-lesion size, } \\
\text { healing signs, } \\
\text { oral function }\end{array}$ & $\begin{array}{l}\text { HA showed better efficacy } \\
\text { in reducing pain and size of } \\
\text { the ulcers compared to } \\
\text { placebo. }\end{array}$ \\
\hline
\end{tabular}

HA: Hyaluronic acid. M: Male. F: Female. NA: not available. VAS: visual analogue scale.

Table 2. CONSORT-based quality analysis of the included studies.

\begin{tabular}{lccccccccc}
\hline Study & & $\mathrm{A}(0-2)$ & $\mathrm{B}(0-2)$ & $\mathrm{C}(0-1)$ & $\mathrm{D}(0-1)$ & $\mathrm{E}(0-2)$ & $\mathrm{F}(0-2)$ & $\mathrm{G}(0-2)$ & Risk of bias \\
\hline${\text { Hashem et al. }{ }^{10}}^{2}$ & 2019 & 0 & 2 & 1 & 1 & 2 & 0 & 2 & High \\
Youssef et al. $^{21}$ & 2019 & 0 & 2 & 1 & 1 & 2 & 0 & 2 & High \\
Sheety et al. $^{22}$ & 2016 & 0 & 2 & 1 & 1 & 2 & 1 & 2 & High \\
Nolan et al. $^{8}$ & 2009 & 2 & 2 & 1 & 1 & 2 & 2 & 2 & Low \\
\hline
\end{tabular}

A: Sample size calculation. B: Randomization and allocation concealment methods. C: Clear definition of inclusion and/or exclusion criteria. D: Withdrawals/dropouts report. E: Baseline comparability of both groups. F: Presence of blinding. G: Appropriate statistical analysis. 


\section{DISCUSSION.}

OLP is one of the most common chronic conditions of oral mucosa. ${ }^{1,2}$ It can cause severe pain and discomfort that severely affects the patient's quality of life.1,11 Although a multitude of treatment modalities have been used, the management of OLP is still challenging with no definitive cure. ${ }^{12} \mathrm{HA}$ has recently been proposed for the management of OLP and showed promising results. ${ }^{8,10,21,22}$ Hence, the present review sought to systematically review the available evidence regarding the clinical efficacy of HA for the management of OLP. The qualitative analysis of the included studies showed that HA is significantly better than a placebo and as effective as triamcinolone in reducing signs and symptoms of OLP. However, due to the limited number of the included studies along with the low quality of some of the included studies, the results of the present review should be interpreted with caution.

One of the primary outcomes assessed in the present review is the efficacy of $\mathrm{HA}$ in reducing subjective symptoms associated with OLP. All included studies reported on this outcome and found that HA is very effective in reducing pain and symptoms of OLP. This indicates that HA has a potent and immediate analgesic effect in reducing pain in OLP patients. The analgesic effects of HA can be explained by its potent antiinflammatory properties. ${ }^{14,17}$ Animal and clinical studies suggest that HA possesses strong anti-inflammatory properties through inhibition of prostaglandin E2 production and other inflammatory mediators. ${ }^{18,19,25}$ HA has been used successfully for the management of several oral and systemic painful inflammatory conditions such as osteoarthritis, temporomandibular joint disorders, aphthous stomatitis. ${ }^{16,17,19,20}$

Another important finding of the present systematic review is the clinical efficacy of HA in reducing the clinical signs of the disease. The included studies showed a significant reduction in the erythema and size of the ulcerative lesion, and the overall healing time; this can be attributed to the known healing promoting actions of HA . ${ }^{14,15}$ The hygroscopic and viscoelastic properties of HA play an important role in the wound healing process. ${ }^{8,15}$ HA has been reported to promote wound healing and re-epithelization through the proliferation of basal keratinocytes and reducing collagen disposition and scarring., ${ }^{8,14,15}$ Our results corroborate previous studies and systematic reviews that reported efficacy of $\mathrm{HA}$ in reducing the healing time of various ulcerative conditions such as leg ulcers, diabetic foot ulcers and recurrent oral ulcers. ${ }^{20,26}$

One important aspect of OLP management is related to the side effects associated with corticosteroids, the mainstay therapy of OLP. Due to the chronic and recurrent nature of the disease, long term use of corticosteroids is mostly associated with numerous adverse effects such as oral candidiasis, mucosal atrophy, taste changes, gastrointestinal disorders, and adrenal insufficiencies. ${ }^{11,12}$ Hyaluronic acid has proven to be safe and well-tolerated with no reported side effects, ${ }^{14}$ and hence HA can be considered as a viable therapeutic option for the management of OLP.

This is the first systematic review on the efficacy of hyaluronic acid for the management of symptomatic OLP. Nonetheless, there are some limitations that should be considered. The key limitation is the limited number of clinical trials included in the present review along with a small sample size in some of these studies. Another important limitation is the low quality of some of the included studies as reflected by the high risk of bias, and thus no robust conclusion can be drawn. Additionally, the marked discrepancy among the included studies with respect to the dose and frequency of the medication, follow-up period, and comparator groups, is an obvious shortcoming.

\section{CONCLUSION.}

In conclusion, the present systematic review shows the positive effects of hyaluronic acid in reducing pain and clinical improvement of patients with OLP. Further clinical trials with stringent methodologies and long follow-up periods are highly recommended.

Conflict of interests: Authors have no conflict of interest to declare.

Ethics approval: None declared.

Funding: None.

Authors' contributions: All authors contributed towards the execution of the study as well as writing and editing of the manuscript.

Acknowledgements: None. 


\section{REFERENCES.}

1. Carrozzo M, Porter S, Mercadante V, Fedele S Oral lichen planus: A disease or a spectrum of tissue reactions? Types, causes, diagnostic algorithms, prognosis, management strategies. Periodontol 2000. 2019;80:105-25.

2. Al-Maweri SA, Al-Jamaei A, Saini R, Laronde DM, Sharhan A White oral mucosal lesions among the Yemeni population and their relation to local oral habits. J Investig Clin Dent. 2018;9:e12305.

3. González-Moles M, Warnakulasuriya S, González-Ruiz I, González-Ruiz L, Ayén Á, Lenouvel D, et al. Worldwide prevalence of oral lichen planus: A systematic review and metaanalysis. Oral Dis. 2020.

4. Alaizari NA, Al-Maweri SA, Al-Shamiri HM, Tarakji B, Shugaa-Addin B Hepatitis C virus infections in oral lichen planus: a systematic review and meta-analysis. Aust Dent J. 2016;61:282-7.

5. DeAngelis LM, Cirillo N, McCullough MJ The immunopathogenesis of oral lichen planus-Is there a role for mucosal associated invariant T cells? Journal of Oral Pathology \& Medicine. 2019;48:552-9.

6. Saini R, Al-Maweri SA, Saini D, Ismail NM, Ismail AR Oral mucosal lesions in non oral habit diabetic patients and association of diabetes mellitus with oral precancerous lesions. Diabetes Res Clin Pract. 2010;89:320-6.

7. Ashraf S, Al-Maweri SA, Alaizari N, Umair A, Ariffin Z, Alhajj MN, Kassim S, Awan KH. The association between Epstein-Barr virus and oral lichen planus: A systematic review and metaanalysis. J Oral Pathol Med. 2020;49(10):969-76.

8. Nolan A, Badminton J, Maguire J, Seymour RA The efficacy of topical hyaluronic acid in the management of oral lichen planus. J Oral Pathol Med. 2009;38:299-303.

9. González-Moles M, Ruiz-Ávila I, González-Ruiz L, Ayén Á, Gil-Montoya JA, Ramos-García P Malignant transformation risk of oral lichen planus: A systematic review and comprehensive meta-analysis. Oral Oncol. 2019;96:121-30.

10. Hashem AS, Issrani R, Elsayed TEE, Prabhu N Topical hyaluronic acid in the management of oral lichen planus: A comparative study. J Investig Clin Dent. 2019;10:e12385.

11. Al-Maweri SA, Ashraf S, Kalakonda B, Halboub E, Petro W, AlAizari NA Efficacy of photodynamic therapy in the treatment of symptomatic oral lichen planus: A systematic review. J Oral Pathol Med. 2018;47:326-32.

12. Yang $H$, Wu $Y$, Ma H, Jiang L, Zeng $X$, Dan H, Zhou Y, Chen Q. Possible alternative therapies for oral lichen planus cases refractory to steroid therapies. Oral Surg Oral Med Oral Pathol Oral Radiol. 2016;121(5):496-509.

13. Al-Maweri SA, Kalakonda B, Al-Soneidar WA, Al-Shamiri HM, Alakhali MS, Alaizari N Efficacy of low-level laser therapy in management of symptomatic oral lichen planus: a systematic review. Lasers Med Sci. 2017;32:1429-37.

14. Vasvani S, Kulkarni P, Rawtani D Hyaluronic acid: a review on its biology, aspects of drug delivery, route of administrations and a special emphasis on its approved marketed products and recent clinical studies. International journal of biological macromolecules. 2020;151:1012-29.
15. Graça MFP, Miguel SP, Cabral CSD, Correia IJ Hyaluronic acid-Based wound dressings: A review. Carbohydr Polym. 2020;241:116364.

16. Bronstone A, Neary JT, Lambert TH, Dasa V Supartz (Sodium Hyaluronate) for the Treatment of Knee Osteoarthritis: A Review of Efficacy and Safety. Clin Med Insights Arthritis Musculoskelet Disord. 2019;12:1179544119835221.

17. Chen LH, Xue JF, Zheng ZY, Shuhaidi M, Thu HE, Hussain $Z$ Hyaluronic acid, an efficient biomacromolecule for treatment of inflammatory skin and joint diseases: A review of recent developments and critical appraisal of preclinical and clinical investigations. Int J Biol Macromol. 2018;116:572-84.

18. Yasuda T Hyaluronan inhibits prostaglandin E2 production via CD44 in U937 human macrophages. Tohoku J Exp Med. 2010;220:229-35.

19. Iturriaga $\vee$, Bornhardt $T$, Manterola C, Brebi P Effect of hyaluronic acid on the regulation of inflammatory mediators in osteoarthritis of the temporomandibular joint: a systematic review. Int J Oral Maxillofac Surg. 2017;46:590-5.

20. Casale M, Moffa A, Vella P, Rinaldi V, Lopez MA, Grimaldi V, et al. Systematic review: the efficacy of topical hyaluronic acid on oral ulcers. J Biol Regul Homeost Agents. 2017;31:63-9.

21. Youssef MI, Darwish ZE, Fahmy RA, El Sayed NM The effect of topically applied hyaluronic acid gel versus topical corticosteroid in the treatment of erosive oral lichen planus. Alexandria Dental Journal. 2019;44:57-63.

22. Shetty RR, Burde KN, Guttal KS The Efficacy of Topical Hyaluronic Acid 0.2\% in the Management of Symptomatic Oral Lichen Planus. J Clin Diagn Res. 2016;10:Zc46-50.

23. Liberati A, Altman DG, Tetzlaff J, Mulrow C, Gøtzsche PC, loannidis JP, Clarke M, Devereaux PJ, Kleijnen J, Moher D. The PRISMA statement for reporting systematic reviews and metaanalyses of studies that evaluate health care interventions: explanation and elaboration. PLoS Med. 2009;6(7):e1000100.

24. Moher D, Hopewell S, Schulz KF, Montori V, Gøtzsche PC, Devereaux PJ, Elbourne D, Egger M, Altman DG; Consolidated Standards of Reporting Trials Group. CONSORT 2010 Explanation and Elaboration: Updated guidelines for reporting parallel group randomised trials. J Clin Epidemiol. 2010;63(8):e1-37

25. Kumahashi $N$, Naitou $K$, Nishi $H$, Oae $K$, Watanabe $Y$, Kuwata S, Ochi M, Ikeda M, Uchio Y. Correlation of changes in pain intensity with synovial fluid adenosine triphosphate levels after treatment of patients with osteoarthritis of the knee with high-molecular-weight hyaluronic acid. Knee. 2011;18(3):160-4.

26. Chen CP, Hung W, Lin SH. Effectiveness of hyaluronic acid for treating diabetic foot: a systematic review and meta-analysis. Dermatol Ther. 2014;27(6):331-6. 